\title{
Animal Manure, Neem Cake, Biochar, Vermicompost or Urea: Choosing the Better Option for Spinacia oleracea Growth and Soil Fertility
}

\author{
Mst. Ummay Salma, Sonia Hossain* \\ Department of Soil, Water and Environment, University of Dhaka, Dhaka, Bangladesh \\ Email: *shbd@du.ac.bd
}

How to cite this paper: Salma, M. and Hossain, S. (2021) Animal Manure, Neem Cake, Biochar, Vermicompost or Urea: Choosing the Better Option for Spinacia oleracea Growth and Soil Fertility. American Journal of Plant Sciences, 12, 1259-1275. https://doi.org/10.4236/ajps.2021.128088

Received: July 5, 2021

Accepted: August 21, 2021

Published: August 24, 2021

Copyright @ 2021 by author(s) and Scientific Research Publishing Inc. This work is licensed under the Creative Commons Attribution International License (CC BY 4.0).

http://creativecommons.org/licenses/by/4.0/

(c) (i) Open Access

\begin{abstract}
Production of safe food through organic farming while maintaining soil sustainability is the crucial challenge of recent time. As such a pot experiment was conducted using animal manure (TAM), neem-cake (TNC), vermicompost (TVC), biochar (TBC) and urea (TU) with control (TC) to assess their capacity to stimulate Spinacia oleracea growth under field condition and their impact on soil fertility. Six treatments: TC, TAM, TNC, TVC, TBC, TU with three replications were used in completely randomized design (CRD). All the plant growth parameters were measured at regular interval up to maturity. Complete chemical analysis of plant tissue, amendments and soil was carried out. Nitrogen use efficiency (NUE) under different treatments was calculated at 45 and 60 days. All the treatments showed statistically significant $(\mathrm{P}<$ $0.001)$ increase in yield over control and urea. The highest plant height (24 $\mathrm{cm})$, leaf area index $(0.154)$, and dry weight $(1254 \mathrm{~kg} / \mathrm{ha})$ were found at TNC which increased respectively $132 \%, 258 \%, 450 \%$ over control and $125 \%$, $431 \%, 448 \%$ over urea. TVC was the second best treatment followed by TBC for plant growth. NUE was significantly $(\mathrm{P}<0.001)$ higher in treatment TVC than any other treatments and was higher at maturity than vegetative state. TNC had lower NUE than TVC and TBC but the inherent $\mathrm{N}$ content was higher in TNC than TVC and TBC. Uptake of certain macro nutrients showed significant $(\mathrm{P}<0.05)$ positive correlation with plant growth parameters i.e., plant height with $\mathrm{P}(\mathrm{R}=0.887)$; leaf area with $\mathrm{N}(\mathrm{R}=0.957)$ and $\mathrm{P}(\mathrm{R}$ $=0.985)$; dry weight with $N(R=0.996), P(R=0.994)$ and $K(R=0.860)$. Significant $(\mathrm{P}<0.001)$ increase in post-harvest soil $\mathrm{C}$ and $\mathrm{CEC}$ content was found with all the treatments. The highest availability of $\mathrm{N}, \mathrm{P}$ and $\mathrm{S}$ was observed under treatment TNC. For short duration crop like spinach, TNC is
\end{abstract}


the best option followed by TVC as they release nutrient quickly than TBC and TAM.

\section{Keywords}

Vermicompost, Neem Cake, Biochar, Spinach, Nitrogen Use Efficiency

\section{Introduction}

Soil is the foundation for food production, so ensuring sustainable management of this resource is crucial to achieve "sustainable development goal" like "zero hunger" and "no poverty" set by UN for countries like Bangladesh. The organic matter status of Bangladesh soil is one of the poorest in the world, ranging between $0.05 \%-0.9 \%$ in most cases with some exception in peat lands and lowlands with more than $2 \%$ on average [1]. Hence, agricultural production in the country largely depends on inorganic fertilizer use, mostly on nitrogen fertilizer. In fact, consumption of nitrogen fertilizer grew substantially from 14.7 - 318.5 kilograms per hectare from 1969-2018 [2]. This trend threatens responsible consumption of the resource and protection of the environment as it can be a source of agricultural non-point pollution through unreasonable fertilization [3] [4].

The key point of soil sustainability is to use the organic resources in an efficient way while decreasing/nullifying the dependence on inorganic amendments and chemicals which is also the main principle of "organic farming". Increasing demand for organic food is causing gradual increase in the number of agricultural land and farm under organic production, which was 43.1 million ha in 2015 [5]. However, the extent of organic farming is too low till today in Bangladesh and horticulture crops are the major organic production. Annual production of 151.3 million ton of cattle manure and 4.52 million ton of poultry manure can be a great resource for organic farming [6]. Use of vermicompost is gaining popularity in Bangladesh due to its easy production, availability and biodegradability. Neem cake, a plant based organic manure, is also getting attention due to its nitrogen richness. Biochar made from field crop residues can also be a good solution to improve soil health and promote plant growth. Addition of these organic manures can significantly contribute to carbon sequestration in soil [7] [8] [9]. The nutrient content in organic manure may be varied due to its composition, source material, moisture percentage, handling method, presence of readily biodegradable compounds etc. Though use of organic manure is good for both soil health and plant growth but improper use may also led to nutrient deficiency or toxicity in soil, groundwater pollution through leaching last but not least economic loss. One of the main challenges in the selecting and using organic manure in the field is to reduce the loss of nitrogen as well as increase nitrogen use efficiency (NUE) and uptake or recovery efficiency [10]. 
Comparative assessment of nutrients for plant uptake and residual soil content from organic amendments like animal manure, vermicompost, neem cake, biochar (made from field available residues) is needed to determine the best organic option available in terms of NUE, soil carbon and nutrient status. Considering all these, the objectives of this work were: 1) to evaluate effects of different organic fertilizers on spinach growth and yield;2) to assess the comparative effects of organic amendments and inorganic fertilizer on the nutrient uptake and nitrogen use efficiency (NUE) of spinach; 3 ) and to determine the physical and chemical changes of the soils.

\section{Materials and Methods}

\subsection{Selection of Soil Sampling Site}

To conduct the following research soil sample was collected from a local vegetable field of Rangpur district, Bangladesh which was a medium highland $\left(25.4560^{\circ} \mathrm{N}\right.$ and $\left.89.3551^{\circ} \mathrm{E}\right)$. The soil belonged to non-calcareous grey floodplain of the Gangachara series which was medium textured, poorly drained, and intermittently flooded.

\subsection{Collection and Preparation of Organic Amendments}

Animal manure (TAM) was prepared by mixing cow-dung and poultry manure in 1:1 ratio. Cow-dung and poultry manure were collected from Pirganj upazilla under Rangpur district, Bangladesh. Neemcake (TNC), a plant based amendment was collected from local market namely Siddique Bazar, Dhaka. The process of neem cake preparation was cold pressing of neem tree fruits and kernels, and the solvent extraction processed for neem oil cake. Vermicompost is the product of the decomposition process using various species of worms, usually red wigglers, white worms, and other earthworms, to create a mixture of decomposing vegetable or food waste, bedding materials, and vermicast. Vermicompost was collected from Nilphamari district. Biochar was prepared from field crop residues by mixing biomass of saw dust, rice husk and rice stubble in 2:2:1 ratio. Biochar was produced by following a simple version of pyrolysis process. Chemical properties of all organic amendments were determined by following standard method, listed in Table 1.

Table 1. Chemical composition of different organic manures.

\begin{tabular}{ccccccccccccc}
\hline Sample & $\mathrm{pH}$ & $\begin{array}{c}\mathrm{C} \\
(\%)\end{array}$ & $\begin{array}{c}\mathrm{CEC} \\
(\%)\end{array}$ & $\begin{array}{c}\mathrm{N} \\
(\%)\end{array}$ & $\begin{array}{c}\mathrm{P} \\
(\%)\end{array}$ & $\begin{array}{c}\mathrm{K} \\
(\%)\end{array}$ & $\begin{array}{c}\mathrm{S} \\
(\%)\end{array}$ & $\begin{array}{c}\mathrm{Ca} \\
(\%)\end{array}$ & $\begin{array}{c}\mathrm{Mg} \\
(\%)\end{array}$ & $\begin{array}{c}\mathrm{Fe} \\
(\%)\end{array}$ & $\begin{array}{c}\mathrm{Mn} \\
(\%)\end{array}$ & $\begin{array}{c}\mathrm{Zn} \\
(\%)\end{array}$ \\
\hline Animal manure (TAM) & 7.65 & 22.14 & 38.00 & 2.70 & 0.25 & 0.40 & 0.43 & 2.46 & 0.08 & 0.02 & 0.005 & 0.007 \\
Neem cake (TNC) & 5.55 & 19.71 & 27.25 & 1.65 & 1.59 & 0.14 & 0.30 & 3.01 & 0.16 & 0.23 & 0.013 & 0.005 \\
Vermicompost (TVC) & 6.91 & 6.50 & 10.25 & 0.78 & 0.89 & 0.06 & 0.71 & 2.87 & 0.17 & 0.31 & 0.029 & 0.012 \\
Biochar (TBC) & 8.92 & 1.83 & 8.45 & 0.76 & 1.77 & 0.89 & 0.07 & 1.22 & 0.93 & 0.41 & 0.159 & 0.022 \\
$\quad$ LSD $_{(0.05)}$ & 0.11 & 3.24 & 2.58 & 0.28 & 0.29 & 0.06 & 0.06 & 0.16 & 0.03 & 0.02 & 0.00 & 0.00 \\
\hline
\end{tabular}




\subsection{Experimental Design and Treatments}

Six different treatments were applied in this experiment, namely, animal manure (TAM), neem cake (TNC), vermicompost (TVC), biochar (TBC), urea (TU) and control (TC). A total of 18 pots with three replications were used to set up the experiment in the net-house of the department of Soil, Water and Environment at the University of Dhaka following a complete randomized design.

\subsection{Pot Preparation and Plant Material}

Plastic pot of $5 \mathrm{~kg}$ sized filled with $4 \mathrm{~kg}$ air dried soil samples were used for this experiment. Each pot was first washed, dried and marked in accordance with the treatments. A leafy-vegetable locally known as Palong Shak, Spinacia oleracea, was selected for this purpose.

\subsection{Application Rate of Organic Amendments and Urea in Soil}

The soil was mixed with different types of organic amendments at a rate of 5 $\mathrm{t} / \mathrm{ha}$, that is, each pot with $4 \mathrm{~kg}$ soil received $10 \mathrm{~g}$ of amendments as per standard recommended practice whereas urea was applied at a rate of $60 \mathrm{~kg} / \mathrm{ha}$, that is, each pot received $0.12 \mathrm{~g}$.

\subsection{Crop Management}

Registered seeds of Spinach were collected from local market of Siddique Bazar, Dhaka and about 9 - 10 seeds were sown in each pot at the net house on January, 2020. The plants were irrigated regularly with tap water and always kept in field capacity condition. The average temperature of the growing season ranged from $16^{\circ} \mathrm{C}-26.5^{\circ} \mathrm{C}$ and relative humidity from $37 \%-55 \%$. Thinning and weed removal was done as and when necessary. Adequate plant protection measures were taken during the growing period. No chemicals or pesticides were used. Visual observations and record of general growth parameters like plant height, leaf area etc., were noted during the whole growth period. The plants were harvested at maturity (60 days). Leaf area index (LAI) was calculated from the multiplication of the length of leaves to width of leaves and dividing the product by the ground area occupied by the plant.

\subsection{Collection and Preparation of Plant Samples}

Plant samples were collected and labeled carefully at 45 days and at 60 days for chemical analysis. The plants were first washed with tap water and then with deionized distilled water followed by separation into two parts: roots and shoots. Fresh weights of both parts were taken. Then all samples were air-dried as well as oven dried at $80^{\circ} \mathrm{C} \pm 5^{\circ} \mathrm{C}$ for 48 hours and dry weights of both parts were taken. The dried samples were then ground with mortar and pestle, mixed thoroughly and passed through a $0.25 \mathrm{~mm}$ sieve and stored in plastic containers for analysis. Standard Nitric-Perchloric acid digestion was carried out for the plant samples for analysis of nutrients like $\mathrm{P}, \mathrm{K}, \mathrm{S}, \mathrm{Ca}$ and $\mathrm{Mg}$ and heavy metals [11]. 


\subsection{Analysis of Plant Samples}

Total nitrogen of the plant samples was determined by Kjeldahl's digestion with concentrated sulfuric acid $\left(\mathrm{H}_{2} \mathrm{SO}_{4}\right)$ as described in Jackson (1973) [11]. The total $\mathrm{K}$ content was determined by using flame photometer (JENWAY, PFP 7) from the digests. The total Phosphorus content of treatments and plant samples were determined colorimetrically using a $\mathrm{HACH}$ spectrophotometer (model no. DR5000) at $490 \mathrm{~nm}$ by developing yellow color with vanadomolybdate after digesting as described in Jackson (1973). Total sulfur content of plant samples were determined by turbidity of suspended barium sulfate using Tween-80 stabilizer. The turbidity was measured by $\mathrm{HACH}$ spectrophotometer (model no. DR5000) at $420 \mathrm{~nm}$ [12]. Total contents of calcium, magnesium and heavy metals of plant samples were determined from the digest by the Varian Atomic Absorption Spectroscopy (AAS) [11].

\subsection{Computation of Nutrient Uptake and Nitrogen Use Efficiency (NUE)}

Using nutrient content data derived from chemical analysis, nutrient uptake was calculated as follows:

Nutrient uptake $(\mathrm{kg} / \mathrm{ha})=$ Nutrient content $(\%) \times$ Dry matter $(\mathrm{kg} / \mathrm{ha}) / 100$

Nitrogen use efficiency of the plants was calculated in two ways using nitrogen uptake data and fresh weight data. They are as follows:

1) Apparent NUE $\left(\mathrm{NUE}_{\mathrm{Ap}}\right)=(\mathrm{N}$ uptake by plant with $\mathrm{N}$ application $-\mathrm{N}$ uptake by plant without $\mathrm{N}$ application)/the amount of $\mathrm{N}$ applied

2) Agronomic NUE $\left(\mathrm{NUE}_{\mathrm{AG}}\right)=\{$ Fresh weight treated $(\mathrm{kg} / \mathrm{ha})-$ Fresh weight in control plot $(\mathrm{kg} / \mathrm{ha})\} /$ Quantity of Nitrogen applied $(\mathrm{kg} / \mathrm{ha})$

\subsection{Analysis of Soil and Organic Amendment Samples}

Various physical, chemical and physicochemical properties of the soil and organic amendments were analyzed in the laboratories. $\mathrm{pH}$ of the samples were measured electrochemically by using a glass electrode $\mathrm{pH}$ meter at a ratio of 1:2.5 for soil and 1:15 for other organic amendments. The CEC of soil and organic amendments were determined by $1 \mathrm{M}$ ammonium acetate extraction method [13]. Total organic carbon was determined by wet oxidation method of Walkley and Black. Total nitrogen was determined by Kjeldahl's digestion method with concentrated sulfuric acid [11] and Micro-Kjeldhal's distillation apparatus was used for distillation. Available phosphorus was determined by extracting the samples using Bray and Kurtz method $(\mathrm{pH}<6.0)$ and Olsen method $(\mathrm{pH}>6.0)$ and then the extracts were used to estimate $\mathrm{P}$ colorimetrically by following the ascorbic acid blue color method using a spectrophotometer at 880 $\mathrm{nm}$. Available $\mathrm{S}$ was determined by extracting the samples with calcium dihydrogen phosphate monohydrate $\left[\mathrm{Ca}\left(\mathrm{H}_{2} \mathrm{PO}_{4}\right)\right.$ and then the turbidity was measured by HACH spectrophotometer (model no. DR5000) at $420 \mathrm{~nm}$. Available K was determined by a flame analyzer after extracting the samples with $1 \mathrm{M}$ am- 
monium acetate at $\mathrm{pH}$ 7.0. Total $\mathrm{P}$ content of the samples were determined colorimetrically using a spectrophotometer at $490 \mathrm{~nm}$ by developing yellow color with vanadomolybdate after digesting the biomass with ternary acid mixture. Total S content of the samples were determined turbidity metrically by a spectrophotometer at $420 \mathrm{~nm}$ after digesting with concentrated nitric and perchloric acid.

Available Calcium and Magnesium of the samples were extracted with $1 \mathrm{~N}$ ammonium acetate at $\mathrm{pH} 7.0$ and determined by the Varian Atomic Absorption Spectroscopy and heavy metals like Iron, Manganese, and Zinc were extracted with DTPA solution at a ratio of 1:2 and determined by the Varian Atomic Absorption Spectroscopy.

\subsection{Statistical Analysis}

Statistical analysis of the experiment data was done by using SPSS (version 20) software and Microsoft Excel (statistical tool pack version 2010).

\section{Results}

\subsection{Effect of Different Organic Amendments on Plant Height and Leaf Area Index}

Growth of plant height remains visibly unaffected by the treatments up to first 10 days but then gradually with time significant differences $(\mathrm{P}<0.001)$ were observed with each treatment (Figure 1(a)). Plant height was consistently higher from germination to maturity with treatment TNC and TBC followed by TVC and TAM whereas TC and TU were consistently lowest; in fact, there was no significant difference between control (TC) and urea application (TU) at maturity (60 days). Though final plant height significantly varied $(\mathrm{P}<0.001)$ among all treatments the variation between TNC and TBC was not statistically significant (Figure 1(b)).

In case of Leaf area index (LAI), the effects of TNC was consistently higher, followed by TVC then by TBC and TAM and statistically significantly different at $1 \%$ level. Surprisingly, the lowest LAI was found with TU which were $32.56 \%$ lower than control (TC) and there was no significant difference between treatment TC and TU in terms of LAI (Figure 2(a)). The highest plant height and LAI both were recorded with treatment TNC but with treatment TBC only the second highest plant height and third highest LAI was recorded which showed treatment TBC was not equally effective on both plant height and LAI (Figure 2(b)). The maximum plant root length $(4 \mathrm{~cm})$ was observed in TVC which was $100 \%$ higher than control and the second maximum plant root length was 3.2 $\mathrm{cm}$ under treatment TBC which was $60 \%$ higher over control. The lowest root growth $(1.9 \mathrm{~cm})$ was observed under treatment TU which was $5 \%$ decreased than control. The ANOVA test showed that significant differential effects of various treatments on root length at $5 \%$ level. 


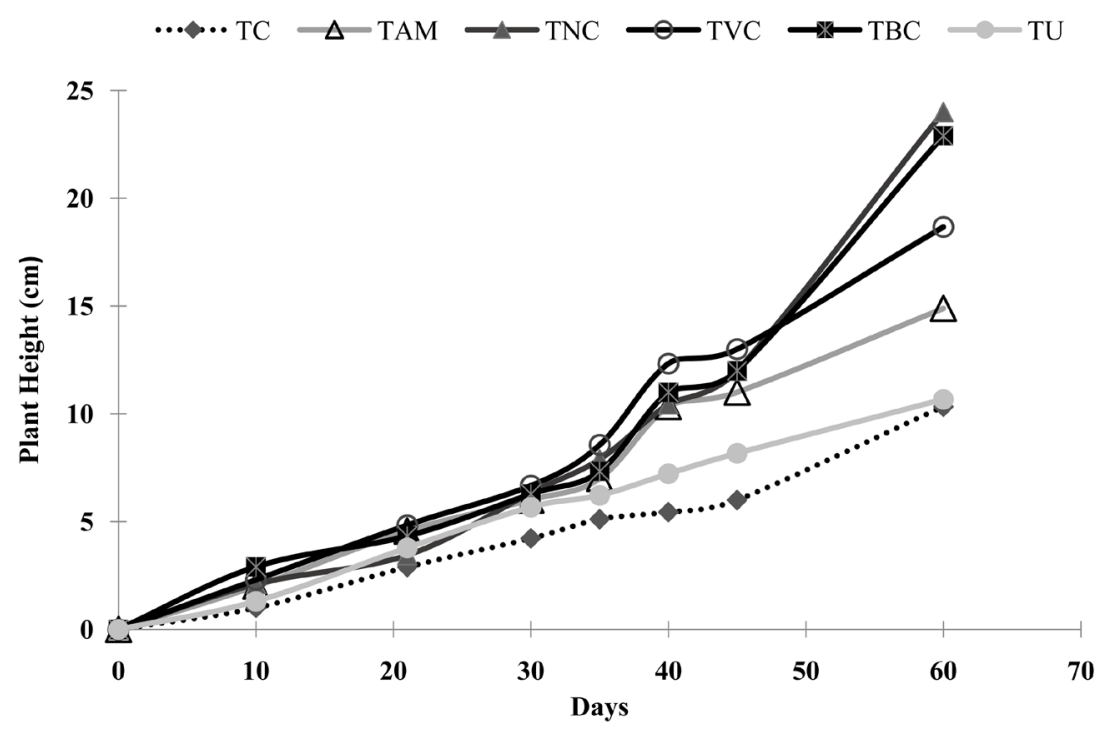

(a)

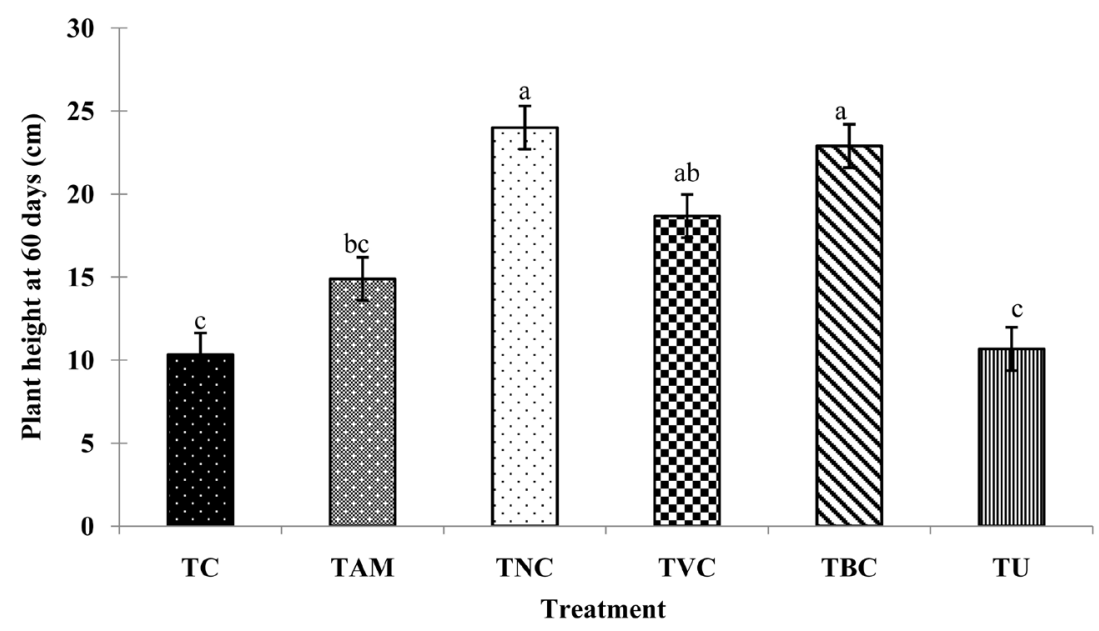

(b)

Figure 1. Plant height of spinach in response to various treatments: (a) Plant height at different days; (b) Plant height at maturity $(\mathrm{LSD}=2.61)$.

\subsection{Effect of Different Organic Amendments on Fresh Weight and Dry Weight}

Differential responses of fresh and dry weight of spinach were recorded under various treatments as shown in Table 2. The maximum fresh weight as well as dry weight of shoot and root was found under treatment TNC followed by TVC then by TBC. Treatment TC and TU had lowest fresh and dry weight. Statistically significant difference in fresh and dry weight was recorded for all the treatments $(\mathrm{P}<0.001)$. However, there was no statistical difference between the highest fresh/dry weight and the second highest fresh/dry weight obtained by treatment TNC and treatment TVC. Similarly, the lowest fresh/dry weight was obtained by TC and TU and there was no statistically significant difference between those two treatments. 


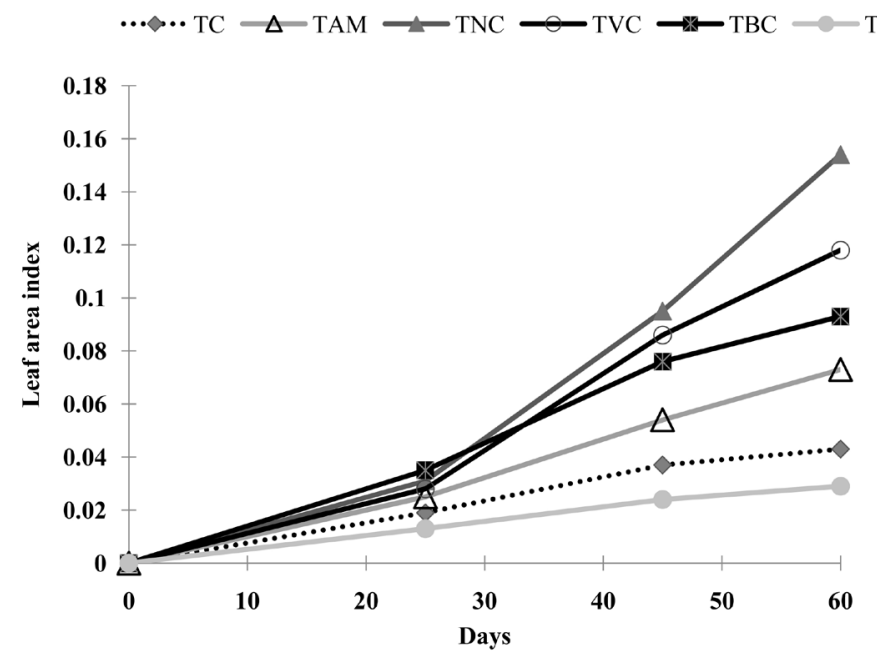

(a)

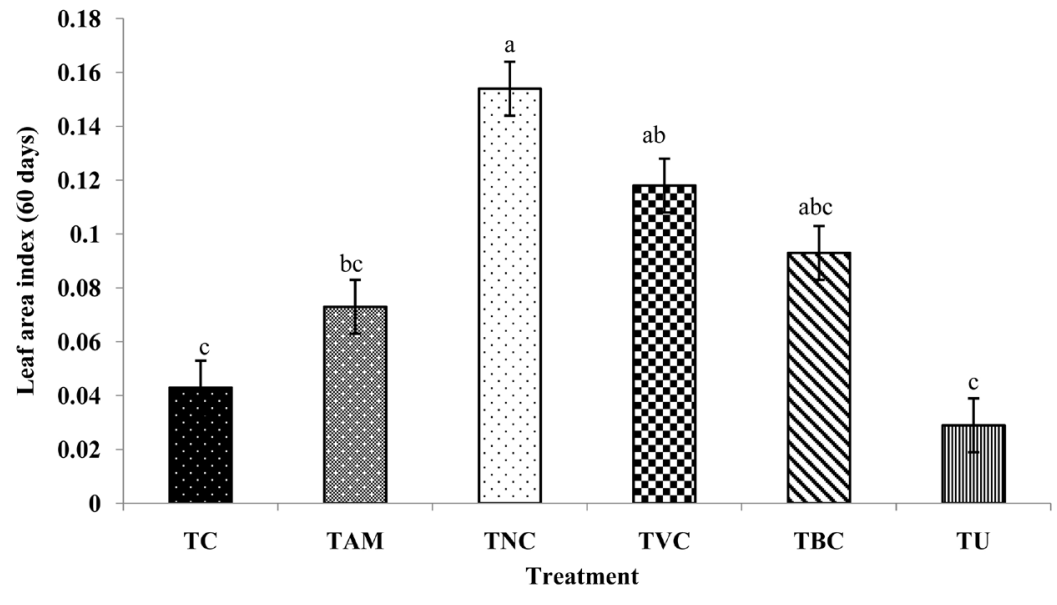

(b)

Figure 2. Leaf area index of spinach under various treatments: (a) LAI at different days and (b) LAI at maturity $(\mathrm{LSD}=0.04)$.

Table 2. Fresh and dry weight of Spinacia oleracea under various treatments.

\begin{tabular}{|c|c|c|c|c|c|c|c|c|c|c|}
\hline \multicolumn{6}{|c|}{ Fresh Weight } & \multicolumn{5}{|c|}{ Dry Weight } \\
\hline \multirow{2}{*}{ Treatment } & \multicolumn{2}{|c|}{$\begin{array}{l}\text { Shoot fresh } \\
\text { weight }\end{array}$} & \multicolumn{2}{|c|}{$\begin{array}{c}\text { Root fresh } \\
\text { weight }\end{array}$} & \multirow{2}{*}{$\begin{array}{c}\text { Total } \\
\text { Fresh } \\
\text { Weight } \\
(\mathrm{kg} / \mathrm{ha})\end{array}$} & \multicolumn{2}{|c|}{$\begin{array}{c}\text { Shoot dry } \\
\text { weight }\end{array}$} & \multicolumn{2}{|c|}{$\begin{array}{c}\text { Root Dry } \\
\text { weight }\end{array}$} & \multirow{2}{*}{$\begin{array}{c}\begin{array}{c}\text { Total } \\
\text { dry } \\
\text { weight }\end{array} \\
(\mathrm{kg} / \mathrm{ha})\end{array}$} \\
\hline & $(\mathrm{kg} / \mathrm{ha})$ & $\begin{array}{c}\text { IOC }^{*} \\
(\%)\end{array}$ & $(\mathrm{kg} / \mathrm{ha})$ & $\begin{array}{c}\text { IOC }^{*} \\
(\%)\end{array}$ & & $(\mathrm{kg} / \mathrm{ha})$ & $\begin{array}{c}\operatorname{IOC}^{*} \\
(\%)\end{array}$ & $(\mathrm{kg} / \mathrm{ha})$ & $\begin{array}{c}\text { IOC }^{*} \\
(\%)\end{array}$ & \\
\hline $\mathrm{TC}$ & 3647 & - & 237 & - & 3883 & 214 & - & 18 & - & 232 \\
\hline TAM & 10,267 & 181 & 398 & 68 & 10,665 & 549 & 157 & 38 & 111 & 587 \\
\hline TNC & 22,292 & 511 & 1053 & 345 & 23,345 & 1155 & 440 & 99 & 450 & 1254 \\
\hline TVC & 20,967 & 474 & 880 & 272 & 21,847 & 1096 & 412 & 84 & 367 & 1180 \\
\hline TBC & 15,532 & 325 & 697 & 194 & 16,228 & 769 & 259 & 76 & 322 & 845 \\
\hline TU & 4183 & 15 & 207 & 12 & 4390 & 209 & 2 & 20 & 11 & 229 \\
\hline $\operatorname{LSD}_{(0.05)}$ & 5000 & - & 190 & - & 5080 & 99 & - & 17 & - & 112 \\
\hline
\end{tabular}

$(\mathrm{TC}=$ Control, $\mathrm{TAM}=$ Animal manure, $\mathrm{TNC}=$ Neem cake, $\mathrm{TVC}=$ Vermicompost, $\mathrm{TBC}=$ Biochar, $\mathrm{TU}=$ Urea). IOC* indicates increase over control in percentage. 


\subsection{Effect of Different Organic Amendments on Macro and Micronutrient Uptake}

Plant nutrient uptake highly depends on the nutrient release from the soil solid phase in the form of mineral and organic materials to the soil solution. The release of nutrients from organic matter occurs biochemically through the balance of mineralization and immobilization processes. The uptake of macronutrients like nitrogen $(\mathrm{N})$, phosphorus $(\mathrm{P})$, potassium $(\mathrm{K})$, sulfur $(\mathrm{S})$, calcium $(\mathrm{Ca})$, and magnesium $(\mathrm{Mg})$ and micronutrients like iron $(\mathrm{Fe})$, manganese $(\mathrm{Mn})$ and Zinc (Zn) by Spinacia oleracea under different treatments are shown in Table 3.

ANOVA test showed significant differential effects of various treatments on nitrogen uptake at $5 \%$ level. Total nitrogen uptake at 45 days and 60 days was consistently highest under same treatment TVC which were $207.64 \%$ and $533.11 \%$ higher than control (TC) respectively. However, the second highest total nitrogen uptake at 45 days and 60 days were accounted for two different treatments which were TBC and TNC respectively with $118.15 \%$ and $528.01 \%$ increase over control (TC). Nitrogen uptake was consistently second lowest at 45 and 60 days under treatment $\mathrm{TU}$ and there was no significant difference between TU and TC uptake. Though nitrogen uptake under TNC initially was lower than TVC and TBC but at maturity uptake spikes up, reached second maximum value and calculated LSD value showed, there was no significant difference between TNC and TVC uptake at 60 days.

The highest uptake of total $\mathrm{P}, \mathrm{S}, \mathrm{Ca}, \mathrm{Fe}$ and $\mathrm{Mn}$ were measured at treatment TNC followed by second highest at TVC (except S). Again, highest uptake of total $\mathrm{K}, \mathrm{Mg}$ and $\mathrm{Zn}$ were measured at TVC followed by second highest at TNC (except K). However, LSD analysis showed that like $\mathrm{N}$ there was no significant difference in uptake of $\mathrm{P}, \mathrm{Ca}$ and $\mathrm{Mg}$ between TVC and TNC. Overall, total macro and micro nutrient uptake were higher in TNC and TVC treatments, especially micro nutrient uptake were higher in TNC. The lowest S, Fe and Zn

Table 3. Macro and micronutrient uptake by Spinacia oleracea under various treatments.

\begin{tabular}{|c|c|c|c|c|c|c|c|c|c|c|}
\hline \multirow{3}{*}{ Treatment } & \multicolumn{7}{|c|}{ Macronutrient uptake (kg/ha) } & \multicolumn{3}{|c|}{ Micronutrient uptake $(\mathrm{kg} / \mathrm{ha})$} \\
\hline & \multicolumn{2}{|c|}{$\mathrm{N}$} & \multirow[b]{2}{*}{$\mathrm{P}$} & \multirow[b]{2}{*}{$\mathrm{K}$} & \multirow[b]{2}{*}{$\mathrm{S}$} & \multirow[b]{2}{*}{$\mathrm{Ca}$} & \multirow[b]{2}{*}{$\mathrm{Mg}$} & \multirow[b]{2}{*}{$\mathrm{Fe}$} & \multirow[b]{2}{*}{$\mathrm{Mn}$} & \multirow[b]{2}{*}{$\mathrm{Zn}$} \\
\hline & $\begin{array}{c}45 \\
\text { days }\end{array}$ & $\begin{array}{c}60 \\
\text { days }\end{array}$ & & & & & & & & \\
\hline TC & 2.338 & 7.430 & 0.556 & 2.660 & 0.053 & 4.790 & 3.090 & 0.528 & 0.124 & 0.089 \\
\hline TAM & 3.811 & 21.866 & 1.920 & 6.190 & 0.513 & 11.92 & 7.476 & 1.084 & 0.142 & 0.139 \\
\hline TNC & 4.674 & 46.661 & 4.880 & 17.67 & 0.783 & 26.16 & 15.06 & 6.770 & 0.410 & 0.217 \\
\hline TVC & 7.192 & 47.040 & 4.090 & 25.57 & 0.473 & 24.51 & 16.42 & 1.987 & 0.272 & 0.331 \\
\hline $\mathrm{TBC}$ & 5.100 & 27.426 & 2.760 & 22.91 & 0.183 & 11.90 & 11.15 & 1.212 & 0.227 & 0.143 \\
\hline $\mathrm{TU}$ & 2.952 & 9.610 & 0.760 & 3.230 & 0.046 & 6.750 & 3.520 & 0.430 & 0.173 & 0.074 \\
\hline $\operatorname{LSD}_{(0.05)}$ & 2.27 & 20.37 & 0.78 & 4.36 & 0.31 & 6.28 & 3.86 & 1.11 & 0.16 & 0.09 \\
\hline
\end{tabular}


uptake were measured at the treatment TU and lowest $\mathrm{P}, \mathrm{K}, \mathrm{Ca}, \mathrm{Mg}$ were at control (TC). ANOVA analysis showed that the effects of different treatments on uptake of $\mathrm{P}, \mathrm{K}, \mathrm{Ca}, \mathrm{Mg}$, and Fe were significant at $1 \%$ level and S, Mn, Zn were at $5 \%$ level.

\subsection{Effect of Different Organic Amendments on Nitrogen Use Efficiency (NUE)}

Although nitrogen use efficiency was calculated by two different methods the results found were similar (Figure 3 ). Apparent nitrogen use efficiency $\left(\mathrm{NUE}_{\mathrm{AP}}\right)$ and agronomic nitrogen use efficiency $\left(\mathrm{NUE}_{\mathrm{AG}}\right)$ measured at 45 days showed the highest efficiency was recorded with treatment TVC followed by TBC and the variation between those two treatments was statistically significant. However, there was no significant difference either in $\mathrm{NUE}_{\mathrm{AP}}(\mathrm{LSD}=0.04)$ or $\mathrm{NUE}_{\mathrm{AG}}$ (LSD $=22.73$ ) at 45 days among treatment TNC, TAM and TU (Figure 3(a), Figure $3(c))$. At maturity, the highest value was recorded with treatment TVC followed by TBC then by TNC in both $\mathrm{NUE}_{\mathrm{AP}}$ and $\mathrm{NUE}_{\mathrm{AG}}$ and there was no significant difference between TAM and TU in terms of NUE in both methods (Figure 3(b), Figure 3(d)).

\subsection{Effect of Different Organic Amendments on Soil Carbon and Other Nutrients}

The physicochemical properties of harvested soil changed from the initial soil after amendments application and plant cultivation as presented in Table 4. Post-harvest soil $\mathrm{pH}$ did not change significantly for any of the treatments and highest increase (0.11) was found for TNC.

One of the main aspects of organic amendment application and agricultural production is to improve soil carbon (C) status. Soil C content increased significantly $(\mathrm{P}<0.001)$ for all the treatments while highest significant increase was

Table 4. Physicochemical properties of post-harvest soil under different treatments (available nutrients status are shown all in $\mathrm{mg} / \mathrm{kg}$ unit).

\begin{tabular}{|c|c|c|c|c|c|c|c|c|c|c|c|c|c|}
\hline Treatment & $\mathrm{pH}$ & $\% \mathrm{C}$ & $C: N$ & $\% \mathrm{CEC}$ & $\mathrm{N}^{*}$ & $\mathrm{P}^{*}$ & $\mathrm{~S}^{*}$ & $\mathrm{~K}^{*}$ & $\mathrm{Ca}^{*}$ & $\mathrm{Mg}^{*}$ & $\mathrm{Fe}^{*}$ & $\mathrm{Mn}^{*}$ & $\mathrm{Zn}^{*}$ \\
\hline In & 5.6 & 0.39 & 4.9 & 5.3 & 18.0 & 44.1 & 12.0 & 377.8 & 242.0 & 200.0 & 970.4 & 190.6 & 10.4 \\
\hline $\mathrm{TC}$ & 5.7 & 0.89 & 6.6 & 6.7 & 60.0 & 38.3 & 9.6 & 409.8 & 626.0 & 132.4 & 782.4 & 139.6 & 8.2 \\
\hline TAM & 5.6 & 1.12 & 8.4 & 5.7 & 70.0 & 52.1 & 8.0 & 426.7 & 596.0 & 139.2 & 800.7 & 134.3 & 8.2 \\
\hline TNC & 5.8 & 1.03 & 6.4 & 9.9 & 100.0 & 71.8 & 15.4 & 358.9 & 595.0 & 154.1 & 761.3 & 159.5 & 7.8 \\
\hline TVC & 5.6 & 1.14 & 7.9 & 6.8 & 100.0 & 61.8 & 9.3 & 412.5 & 569.0 & 155.8 & 710.5 & 129.5 & 8.0 \\
\hline ТВC & 5.8 & 1.27 & 8.1 & 10.4 & 70.0 & 55.6 & 5.6 & 412.6 & 632.0 & 189.1 & 723.7 & 162.7 & 6.7 \\
\hline TU & 5.5 & 1.11 & 8.1 & 4.7 & 70.0 & 46.9 & 9.3 & 390.0 & 472.0 & 142.7 & 880.9 & 158.0 & 7.4 \\
\hline $\operatorname{LSD}_{(0.05)}$ & 0.41 & 0.07 & - & 0.5 & 4.7 & 6.2 & 2.0 & 19.6 & 89.3 & 14.2 & 42.3 & 18.6 & 0.5 \\
\hline
\end{tabular}




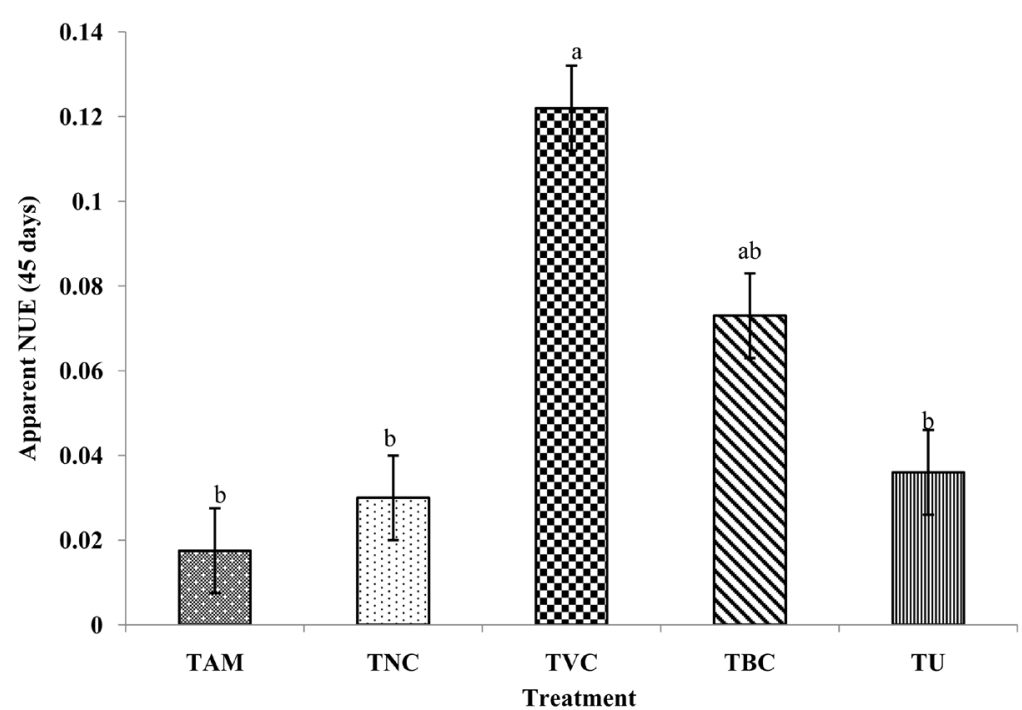

(a)

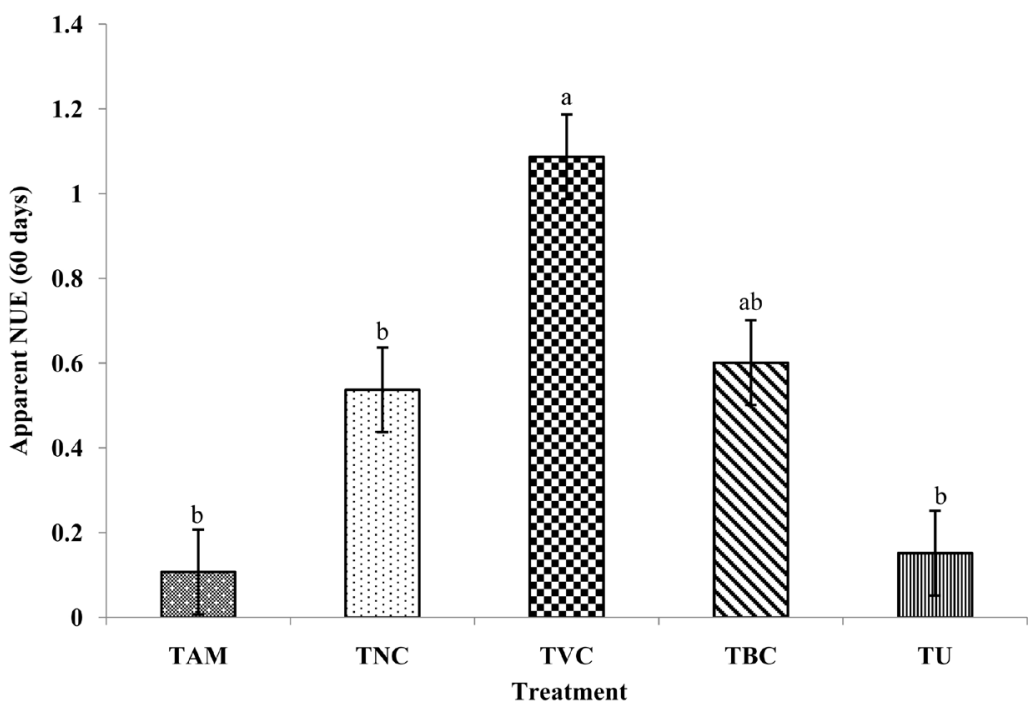

(b)

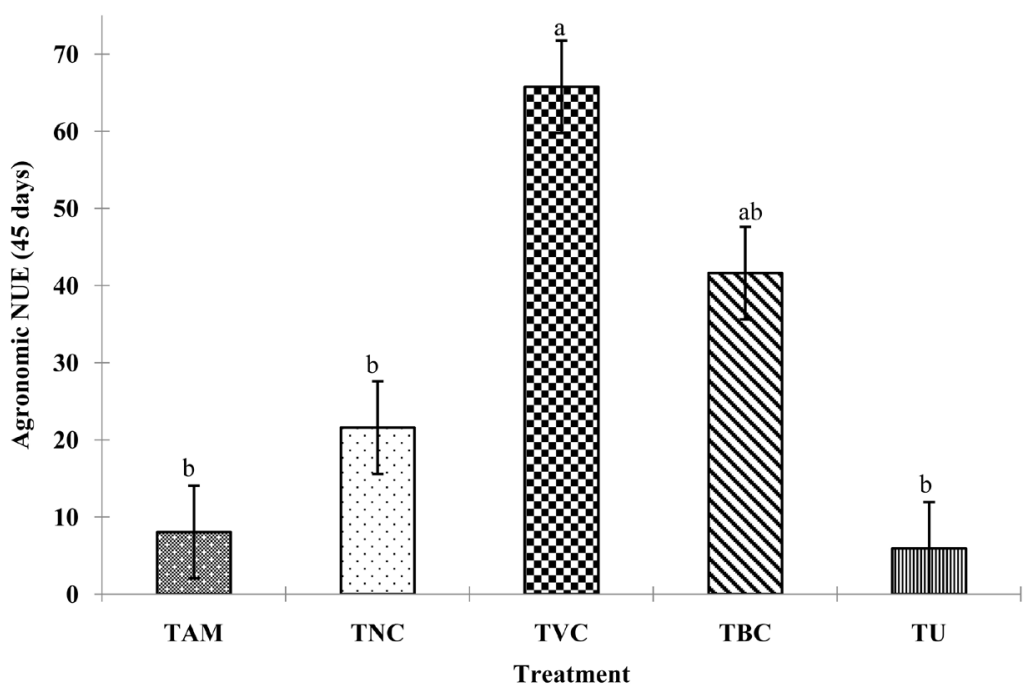

(c) 


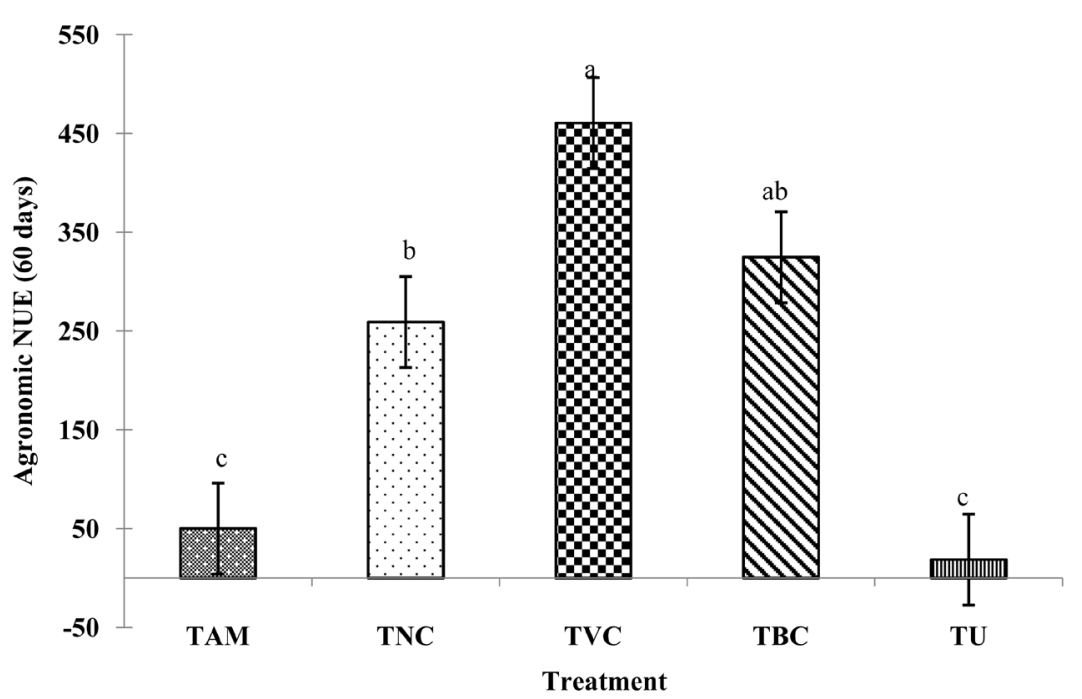

(d)

Figure 3. Nitrogen use efficiency of Spinacia Olercea under different treatments: (a) $\mathrm{NUE}_{\mathrm{AP}}$ at 45 days and (b) $\mathrm{NUE}_{\mathrm{AP}}$ at 60 days $(\mathrm{P}<0.001)$; (c) $\mathrm{NUE}_{\mathrm{AG}}$ at 45 days and (d) $\mathrm{NUE}_{\mathrm{AG}}$ at 60 days $(\mathrm{P}<0.001)$.

recorded with TBC followed by TVC and lowest was with TC. The highest available $\mathrm{N}$ content was determined at treatment TNC and TVC simultaneously and lowest $\mathrm{N}$ was determined at TC $(\mathrm{P}<0.05)$. The ratio of total soil $\mathrm{C}$ and $\mathrm{N}$ content (C: $\mathrm{N}$ ) increased due to amendment application and highest $\mathrm{C}: \mathrm{N}$ value was 8.36 found with TAM while lowest was 6.40 found with TNC. To maintain good soil health and productivity in agricultural soil higher C: $\mathrm{N}$ (at least 10) is preferred and this increase was found with all treatments in post-harvest soil.

Application of organic amendments significantly $(\mathrm{P}<0.001)$ increased cation exchange capacity (CEC) of the soil. The highest CEC value was found with TBC and TNC whereas lowest with urea. The available $\mathrm{P}$ content increased from initial soil in all the treatments significantly $(\mathrm{P}<0.001)$ except control. The highest and second highest available P content were recorded in treatment TNC and TVC which was $87.55 \%$ and $61.49 \%$ higher over the control. The available $S$ content decreased in all most all treatments significantly $(\mathrm{P}<0.001)$ except TNC and this increase was $61.13 \%$ higher over the control. The available $\mathrm{K}$ content increased in all most all treatments significantly $(\mathrm{P}<0.001)$ except TNC. The highest available $\mathrm{K}$ content was recorded in treatment TAM and second highest in treatment TVC, TBC. The available Ca content increased from initial soil in all the treatments significantly $(\mathrm{P}<0.05)$. The highest content of $\mathrm{Ca}$ was found in TBC followed by control. Like S, the available Mg content decreased from initial soil in all the treatments significantly $(\mathrm{P}<0.001)$ and the highest content was found in TBC. Following the same trend, the available heavy metal like Fe, $\mathrm{Mn}$, $\mathrm{Zn}$ content in post-harvest soil decreased from initial soil significantly $(\mathrm{P}<$ 0.001) and the highest value for Fe, Mn and $\mathrm{Zn}$ were found with TU, TBC and TAM respectively. It should be mentioned that initial and post-harvest soil had heavy metal content well below critical limit. 


\section{Discussion}

This study showed that all the growth parameters like, plant height, leaf area index (LAI) and root length of spinach were significantly $(\mathrm{P}<0.001)$ increased under organic amendments application compare to control and urea treatment. However, mixed responses have been reported for applications of organic manures for vegetable production. Vermicompost, cow dung, poultry manure, neem cake, mustard cake were found effective in the production of cowpea and yield was as good as those found with inorganic fertilizer application [14]. Lettuce yield increased under organic amendment application compare to unfertilized soil [15]. Again, decreased in lettuce growth with increasing rates of the organic fertilizer was also found [16]. Similarly, cattle manure was found less effective compare to diammonium phosphate in amaranth yield [17] while poultry manure increased amaranth growth and nitrogen uptake compared to urea [18]. Animal (sheep) manure increased nitrogen content and yield of rapeseed significantly over control [19]. In this experiment, application of animal manure (cow-dung and poultry manure in 1:1 ratio) increased fresh yield significantly ( $\mathrm{P}$ $<0.001$ ) over control and urea which was in agreement with the previously mentioned studies but this increase was lower than biochar, vermicompost and neem cake applications.

Reportedly, biochar treatment had significantly higher yield, plant $\mathrm{N}$ uptake, and NUE in water spinach (Ipomoea aquatica L.) compare to chemical fertilizer and reduced $\mathrm{N}$ loss in open field trial [20]. Conversely, Biochar also reduced maize dry matter yield by $15.6 \%$ in comparison to the untreated control with lower NUE indicating $\mathrm{N}$ immobilization by biochar at low $\mathrm{N}$ rates [21]. Total yield and $\mathrm{N}$ uptake of Chinese flowering cabbage were significantly higher under combination of composted cow dung and biochar $(8.5 \mathrm{t} / \mathrm{ha})$ treatment than composted cow dung treatment alone [22]. In this experiment, application of biochar also increased yield significantly $(\mathrm{P}<0.001)$ over control and urea but this increase was $34.62 \%$ and $43.85 \%$ lower than vermicompost and neem cake treatment, respectively.

The second highest dry and fresh yield was recorded with vermicompost application largely due to higher LAI and the yield difference between highest and second highest was not significant. Previously, spinach plants with $10 \%$ vermicompost as soil amendment had highest leaf number, area, and fresh weight which were similar to this experiment [23]. Vermicompost application increased yield of bell paper [24] eggplant [25] and maize [26] under water deficit conditions alone or in combination with biochar.

Under the treatment TNC (neem cake) the plant height $(24 \mathrm{~cm})$ and the leaf area index (0.154), fresh weight of shoot $(22,292 \mathrm{~kg} / \mathrm{ha})$ and root $(1053 \mathrm{~kg} / \mathrm{ha})$ were highest. Dry biomass is the indication of organic matter of a particular plant. The maximum dry weight for shoot $(1155 \mathrm{~kg} / \mathrm{ha})$ and root $(99 \mathrm{~kg} / \mathrm{ha})$ of spinach were highest at treatment TNC. Some studies showed that by applying neem seed cake significantly affected the growth and yield parameters of okra 
[27]. Neem Cake (NC) application also been reported to increase the dry matter yield of wheat significantly [28]. Dissimilar result was reported that the increase in nitrogen fertilizer resulted in a decrease in dry matter percentage [29].

Uptake of maximum macro and micronutrient occurred under the treatment TNC followed by the treatment TVC. In comparison with the inorganic fertilizer urea (TU), organic amendment showed better result in macronutrient uptake under various treatments. Nitrogen uptake showed highly positive correlation with plant height $(\mathrm{R}=0.828)$, leaf area $(\mathrm{R}=0.9568)$, dry weight $(\mathrm{R}=0.996)$ and uptake of $\mathrm{P}(\mathrm{R}=0.983), \mathrm{Ca}(\mathrm{R}=0.985), \mathrm{Mg}(\mathrm{R}=0.9897), \mathrm{Mn}(\mathrm{R}=0.8342)$ and $\mathrm{Zn}(\mathrm{R}=0.9113)$ that were significant at $5 \%$ level. There were no statistically significant relationships among nitrogen uptake and potassium, sulfur and iron uptake. It was clearly observed that high nitrogen uptake can increase plant height, leaf area, dry weight as well as other macro and micronutrient uptake as it had a synergistic relationship with plant growth and yield parameters and macro and micro nutrient uptake. Previous studies found that application of organic manures favored the uptake of N, K and S in wheat [30] and they showed significant effects on $\mathrm{N}, \mathrm{P}$ and $\mathrm{K}$ content of the cabbage crop than control [31].

In this study, nitrogen use efficiency (NUE) increased significantly $(\mathrm{P}<0.001)$ with the addition of organic amendments compare to control and urea. The highest NUE was recorded with TVC (vermicompost) although total nitrogen content in TVC was lower than TAM and TNC. Then again, TNC had lower NUE compare to TVC and also to TBC. All these revealed that, there was a negative correlation $(\mathrm{R}=-0.732)$ between nitrogen uptake and total content in the organic amendments. NUE of spinach also varied with days as it increased at the later part of the growth period than earlier.

It was observed that the application of organic amendments in this experiment significantly increased soil cation exchange capacity $(\mathrm{P}<0.001)$ and soil organic matter content $(\mathrm{P}<0.001)$ and also changed the availability of macro and micro nutrients for plant growth. Similar findings were reported for vermicompost and poultry manure application in okra-rice cropping system which also exhibited liming effect to some extent [32]. The available macronutrients content increased under organic amendment treatments compare to initial soil content, particularly soil available $\mathrm{P}$ content increased significantly $(\mathrm{P}<0.001)$. Biochar (TBC) was the best treatment in terms of increasing soil $\mathrm{C}$ content and CEC. Treatment TNC and TVC had the highest soil available nitrogen content compared to other treatments. It should be mentioned that highest percentage of $\mathrm{C}, \mathrm{N}$ and CEC was found with animal manure (TAM) but the result was not reflected on the changes of post-harvest soil nutrient status and also on plant growth. Neem cake (TNC) showed best results for restoring most macro nutrients like available N, P, S content except K and vermicompost (TVC) closely followed.

\section{Conclusion}

After analyzing the plant morphological properties and yield parameters, the 
best results were recorded in the Neem cake (TNC) treatment. It was also the best treatment for improving soil nutrient (C, N, P, S) status as plant height; leaf area and dry weight were highly correlated with $\mathrm{N}$ and $\mathrm{P}$ uptake. This treatment was statistically the best treatment among other treatments. Vermicompost (TVC) treatment had the second best result in terms of plant growth and soil fertility which might be due to higher NUE of spinach plant under this treatment. Although, urea is commonly used nitrogen fertilizer, here it was shown that the organic amendment worked better than the area in the terms of nitrogen use efficiency. It indicated that, organic amendments might be better source with high NUE for long duration crops than short duration crops like spinach.

\section{Conflicts of Interest}

The authors declare no conflicts of interest regarding the publication of this paper.

\section{References}

[1] Huq, S.M.I. and Shoaib, J.U.M. (2013) The Soils of Bangladesh. Springer, New York, 3-4. https://doi.org/10.1007/978-94-007-1128-0

[2] World Data Atlas (2018) Fertilizer Consumption. https://knoema.com/atlas/Bangladesh/Fertilizer-consumption

[3] Eriksen, J., Askegaard, M., Rasmussen, J. and Soegaard, K. (2015) Nitrate Leaching and Residual Effect in Dairy Crop Rotations with Grass-Clover Leys as Influenced by Sward Age, Grazing, Cutting and Fertilizer Regimes. Agriculture, Ecosystems \& Environment, 212, 75-84. https://doi.org/10.1016/j.agee.2015.07.001

[4] Kourakos, G., Klein, F., Cortis, A. and Harter, T. (2012) A Groundwater Nonpoint Source Pollution Modeling Framework to Evaluate Long-Term Dynamics of Pollutant Exceedance Probabilities in Wells and Other Discharge Locations. Water Resources Research, 48, 2805-2814. https://doi.org/10.1029/2011WR010813

[5] FiBL and IFOAM (2015) The World of Organic Agriculture: Statistics and Emerging Trends. Bonn, Germany, 36-63.

[6] Huque, K.S. (2015) Draft National Integrated Livestock Manure Management (ILMM) Policy. Government of the People's Republic of Bangladesh, Ministry of Fisheries and Livestock, Dhaka, 1-5.

[7] Spaccini, R., Piccolo, A., Conte, P., Haberhauer, G. and Gerzabek, M.H. (2002) Increased Soil Organic Carbon Sequestration through Hydrophobic Protection by Humic Substances. Soil Biology and Biochemistry, 34, 1839-1851.

https://doi.org/10.1016/S0038-0717(02)00197-9

[8] Gerzabek, M.H., Pichlmayer, F., Kirchmann, H. and Haberhauer, G. (1997) The Response of Soil Organic Matter to Manure Amendments in a Long term Experiment at Ultuna, Sweden. European Journal of Soil Science, 48, 273-282. https://doi.org/10.1111/j.1365-2389.1997.tb00547.x

[9] Glaser, B., Lehman, J., Fuhrboter, M., Solomon, D. and Zech, W. (2001) Carbon and Nitrogen Mineralization in Cultivated and Natural Savanna Soils of Northern Tanzania. Biology and Fertility of Soils, 33, 301-309. https://doi.org/10.1007/s003740000324

[10] Moe, K., Mg, K.W., Win, K.K. and Yamakawa, T. (2017) Effects of Combined Ap- 
plication of Inorganic Fertilizer and Organic Manures on Nitrogen Use and Recovery Efficiencies of Hybrid Rice (Palethwe-1). American Journal of Plant Sciences, 8 , 1043-1064. https://doi.org/10.4236/ajps.2017.85069

[11] Jackson, M.L. (1973) Soil Chemical Analysis. Publisher-Prentice-Hall of India Pvt. Ltd., New Delhi, 1-498.

[12] Page, A.L., Miller, R.H. and Keeney, D.R. (1989) Methods of Soil Analysis. Part-2, 2nd Edition, American Society of Agronomy, Wisconsin.

[13] Schollenberger, C.J. and Simon, R.H. (1945) Determination of Exchange Capacity and Exchangeable Bases in Soil-Ammonium Acetate Method. Soil Conditioning Index, 59, 13-24. https://doi.org/10.1097/00010694-194501000-00004

[14] Panda, P.K., Nandi, A., Swain, P.K., Patnaik, S.K. and Patnaik, M. (2012) Soil Amendment on Growth, Nodulation, Yield, Soil Health, and Economics of Cowpea. International Journal of Vegetable Science, 18, 284-297. https://doi.org/10.1080/19315260.2011.642474

[15] Montemurro, F. (2010) Are Organic N Fertilizing Strategies able to Improve Lettuce Yield, Use of Nitrogen and N Status? Journal of Plant Nutrition, 33, 1980-1997. https://doi.org/10.1080/01904167.2010.512056

[16] Brito, L.M., Sampaio, A., Pinto, R., Mourão, I. and Coutinho, J. (2016) Lettuce Response to Organic and Phosphate Fertilizers and Root Mycorrhization. Journal of Plant Nutrition, 39, 842-849. https://doi.org/10.1080/01904167.2015.1106557

[17] Cecilia, M.O., Harbinson, J., Jasper K.I., Shibairo, S.S. and Kooten, O.V. (2012) Influence of Organic and Mineral Fertilization on Germination, Leaf Nitrogen, Nitrate Accumulation and Yield of Vegetable Amaranth. Journal of Plant Nutrition, 35, 342-365. https://doi.org/10.1080/01904167.2012.639917

[18] Olatoberu, F.T., Idowu, M.K., Adepetu, J.A. and Akinremi, O.O. (2019) Differential Response of Biomass Production and Nitrogen Uptake of Vegetable Amaranth to Two Types of Poultry Manure from Nigeria and Canada. Food and Nutrition Sciences, 10, 694-711. https://doi.org/10.4236/fns.2019.106051

[19] Naderi, R., Bijanzadeh, E., Nosrati, K. and Egan, T.P. (2016) The Effect of Composted Municipal Waste, Sheep Manure, and Urea Nitrogen on the Growth and Chemical Composition of Two Rapeseed Cultivars. Journal of Plant Nutrition, 39, 1328-1335. https://doi.org/10.1080/01904167.2015.1043382

[20] Zhou, M., Ying, S., Chen, J.P., and Teng, Y. (2021) Effects of Biochar-Based Fertilizer on Nitrogen Use Efficiency and Nitrogen Losses via Leaching and Ammonia volatilization from an Open Vegetable Field. Environmental Science and Pollution Research. https://doi.org/10.1007/s11356-021-15210-9

[21] Rodrigues, M.Â., Torres, L.D.D., Damo, L., Raimundo, S., Sartor, L., Cassol, L.C., and Arrobas, M. (2021) Nitrogen Use Efficiency and Crop Yield in Four Successive Crops Following Application of Biochar and Zeolites. Journal of Soil Science and Plant Nutrition, 21, 1053-1065. https://doi.org/10.1007/s42729-021-00421-3

[22] Wang, Z., Li, Y.K., Guo, W., Xu, Z., Wang, L., and Ma, L. (2019) Yield, Nitrogen Use Efficiency and Economic Benefits of Biochar Additions to Chinese Flowering Cabbage in Northwest China. Nutrient Cycling in Agroecosystems, 113, 337-348. https://doi.org/10.1007/s10705-019-09971-6

[23] Peyvast, G.H., Madeni, S., Olfati, J.A. and Forghani, A. (2008) Effect of Vermicompost on the Growth and Yield of Spinach (Spinacia oleracea L.). Journal of Food Agriculture and Environment, 6, 110-113.

[24] Llaven, M.A.O., Jimenez, J.L.G., Coro, B.I.C., Rosales, R.R., Molina, J.M., Dendooven, L. and Gutiérrez-Miceli, F.A. (2008) Fruit Characteristics of Bell Pepper Culti- 
vated in Sheep Manure Vermicompost Substituted Soil. Journal of Plant Nutrition, 31, 1585-1598. https://doi.org/10.1080/01904160802244738

[25] Ebrahimi, M., Souri, M.K., Mousavi, A. and Sahebani, N. (2021) Biochar and Vermicompost Improve Growth and Physiological Traits of Eggplant (Solanumm elongena L.) under Deficit Irrigation. Journal of Agricultural Science and Technology, 8, 19. https://doi.org/10.1186/s40538-021-00216-9

[26] Doan, T.T., Henry-des-Tureaux, T., Rumpel, C., Janeau, J.L. and Jouquet, P. (2015) Impact of Compost, Vermicompost and Biochar on Soil Fertility, Maize Yield and Soil Erosion in Northern Vietnam: A Three Year Mesocosm Experiment. Science of the Total Environment, 514, 147-154.

https://doi.org/10.1016/j.scitotenv.2015.02.005

[27] Eifediyi, E.K., Mohammed, K.O. and Remison, S.U. (2015) Effect of Neem (Azadirachta indica L.) Seed Cake on the Growth and Yield of Okra (Abelmoschus esculentus L.). Poljoprivredal Agriculture, 21, 46-52.

https://doi.org/10.18047/poljo.21.1.8

[28] Saha, S., Antil, R.S., Saha, B.N. and Dahiya, D.S. (2018) Effect of Neem Cake and N on the Yield and Uptake of Nutrients by Wheat. Crop Research, 44, 251-254.

[29] Elia, A., Santamaria, P. and Serio, F. (1998) Nitrogen Nutrition Yield and Quality of Spinach. Journal of the Science of Food and Agriculture, 76, 341-346. https://doi.org/10.1002/(SICI)1097-0010(199803)76:3<341::AID-JSFA938>3.0.CO;2 $\underline{-4}$

[30] Malhi, S.S. (2012) Relative Effectiveness of Various Amendments in Improving Yield and Nutrient Uptake under Organic Crop Production. Open Journal of Soil Science, 2, 299-311. https://doi.org/10.4236/ojss.2012.23036

[31] Vimala, P., Illias, M.K. and Salbiah, H. (2006) Effect of Rates of Organic Fertiliser on Growth, Yield and Nutrient Content of Cabbage (Brassica oleracea var. capitata) Grown under Shelter. Acta Horticulturae, 710, 391-398. https://doi.org/10.17660/ActaHortic.2006.710.47

[32] Velmurugan, A. and Swarnam, P. (2017) Nutrient Uptake and Residual Effect of Organic Treatments Applied to Vegetable-Rice System in an Acid Soil. Journal of Plant Nutrition, 40, 1755-1772. https://doi.org/10.1080/01904167.2016.1236944 